\title{
The economic effects of the territoriality principle
}

\author{
Evidence from Transylvania, Romania
}

\author{
Zsombor Csata, ${ }^{1,2}$ Roman Hlatky, Amy H. Liu,, and \\ Ariel Pitre Young ${ }^{3}$ \\ ${ }^{1}$ Babeş-Bolyai University $\mid{ }^{2}$ Center for Social Sciences, Hungary \\ ${ }^{3}$ University of Texas at Austin
}

The territoriality principle stipulates that minority communities in a given territory should be linguistically accommodated. What are the economic effects of this principle? In this paper, we argue that the recognition of multiple languages confers respect on the minority group; it allows people to engage and participate meaningfully in society - thereby facilitating economic well-being. There is, however, a caveat: when recognition happens in areas where the minority is the overwhelming majority, there is a risk that the near-exclusive use of the minority language cuts the community off from the larger national state, which in turn stunts development. To test this, we focus on Transylvania, Romania. We leverage a legal stipulation that recognizes minority languages in areas where the minority constitutes more than $20 \%$ of the population. Using data at the municipal level, we find that recognition increases economic well-being in general - but not in areas where the minority are numerically dominant. Our results are normatively welcoming, but they also caution governments not simply to recognize minority languages but also to protect them adequately.

Keywords: economic development, linguistic diversity, minority accommodation, Romania, territoriality principle, Transylvania

\section{Introduction}

What are the economic effects of the territoriality principle - i.e., the accommodation of linguistic minorities in a given area (De Schutter, 2008)? The territoriality principle stipulates minority language use in official matters - whether exclusively as is the case in Switzerland or in conjunction with the majority language as in 
the case of Finland. In theory, such recognition should have broader economic implications. The provision of minority language rights sends a message of cultural worth; it promotes social egalitarianism and in some cases even economic efficiency, thereby reducing costs of transacting across languages and encouraging collaboration. In this article, we investigate this link.

To test this relationship, we focus on Transylvania, Romania. The region is home to a diverse community, including a sizable Hungarian minority - one of the largest ethno-linguistic minorities in Europe (Wolff, 2009) and a legacy of World War $1 .{ }^{1}$ Moreover, we are able to employ a quasi-natural experiment given the nature of language laws in Romania. The law considers a minority language as a working language in an administrative unit when the group comprises at least $20 \%$ of the area's population. Within Romania, most of these bilingual (if not trilingual) areas are in Transylvania. Moreover, Transylvania is home to 16 counties - including the only two in Romania where an ethnic minority constitutes the majority. Using data at the municipal level, we find that minority language recognition has a positive effect on four different measures of economic well-being: municipal revenues, human development index, business activity, and housing stock. Note that all four indicators are departures from conventional measures used in the literature on the economic impact of linguistic skills or language policies (e.g., GDP per capita, economic growth, or public goods spending). The fact that we find similar effects nonetheless is an important innovation and contribution. There is, however, an important caveat. The observed effects are conditioned on linguistic diversity. When the minority is the numerical supermajority, there is the risk that the (perceived) monopolistic use of the minority language cuts off the community from the larger national state, which in turn hinders economic wellbeing.

The paper proceeds as follows. In the next section we review the literature on the purported link between the territoriality principle and economic outcomes. We focus on the mechanisms that underlie this relationship. We then discuss how linguistic diversity can exacerbate or attenuate the effects of minority language recognition. In section four, we present the research design, detailing the

1. Before World War I - while still under Austro-Hungarian rule $-53.7 \%$ of the Transylvania population spoke Romanian; 31.6\%, Hungarian; $10.7 \%$, German; and 4\%, another minority language (e.g., Ruthenian or Serbian). At that time, Hungarian-speaking Jews and Roma were classified as native Hungarian speakers (Boia, 2015). These numbers have significantly changed since then with the Holocaust, post-World War II assimilation pressures, and subsequent emigration waves. Today, the Romanian-speakers constitute $74.3 \%$ of the Transylvania population (2011 census). In contrast, the Hungarians have decreased to 19.5\%; the German-speaking community has dropped even more dramatically to $0.4 \%$. Romani is the mother tongue for $1.6 \%$ of the Transylvanian population. 
municipal-level data used for our analyses. We then present the empirical results in section five. We conclude by discussing the theoretical contributions and policy implications of these findings.

\section{The territoriality principle and minority language recognition}

The territoriality principle states that when a linguistic minority is sufficiently large in an area, the linguistic-territorial unit should have the right to selfgovernance over matters of linguistic issues (De Schutter, 2008, p.107). This accommodation has implications for economic development. On the one hand, recognition of multiple languages is costly. Translating paperwork and interpreting government communications require money and time - and even then, mistakes still happen. The implications of these mistakes are not always trivial (see Liu, 2015). Moreover, adopting and implementing minority language rights are important symbolic elements for strengthening ethnic boundaries (Toró, 2020, p.6). This may lead to a decrease in interethnic contact, and minority groups might end up operating in parallel track without engaging those in the majority (Csata, 2018). Less contact also means that generalized trust of the outgroup is less likely to manifest itself. The absence of generalized trust limits economic transactions (Knack and Keefer, 1997), and increases the transaction cost of cooperation at the boundaries (den Butter and Mosch, 2003). Finally, if the resources earmarked for accommodating the minority language are relatively limited - i.e., there are few minority language speakers in municipal government offices - this can result in minority dissatisfaction and limited interaction with the state. All of this - i.e., inefficiency, lack of generalized trust, and dissatisfaction with the state hampers economic cooperation and income accrual.

On the other hand, when governments recognize second languages in a subnational unit, the nature of engagement shifts between the linguistic minority and the state. Minorities can communicate with government employees and complete all paperwork in their mother tongue. This engagement is necessary for socioeconomic enfranchisement (Ginsburgh and Weber, 2011). Symbolic recognition is also at play. When governments recognize a minority language, this suggests its speakers are of worth - thereby signaling 'parity of esteem' (Van Parijs, 2011). This signaling is important: such recognition can translate into government legitimacy from the minority group perspective (see Liu and Baird, 2012; Liu, 2015; Marquardt, 2018; Ricks, 2020). Finally, minority language recognition can encourage speakers of each language to learn the other language - thereby facilitating cultural understanding even if proficiency is far from perfect (Liu, Brown, and Dunn, 2015). All of this - confidence in political institutions, height- 
ened self-esteem, and generalized trust - is what induces economic development (see Putnam, 2007).

One reason for this theoretical impasse - i.e., whether minority language recognition hampers or facilitates economic development - is that discussions of the territoriality principle are premised on something binary. The focus is often on whether a minority language population surpasses some arbitrary threshold. If it does, the language is afforded recognition; otherwise, it is not. But focusing strictly on a numerical threshold implicitly ignores the linguistic diversity of the entire territory. There is little consideration for the size of the majority population; indeed it is possible the hegemonic group only has a plurality - if even that. Moreover, there is no attention on what other linguistic minorities exist in the territory. Put differently, consider a territory where there is minority language recognition. There is a substantive difference between (1) a minority population that barely passes the threshold; (2) a minority population that is roughly 50-50 in size with the majority; and (3) a minority population that is actually the majority in the given locality. The ability of the linguistic minority to wield influence and extract resources from the state depend on its size. Additionally, there is a qualitative difference between (1) the recognition of just one (of several) minority languages; and (2) the recognition of multiple minority languages. The former scenario can create resentment among the minorities who do not have linguistic accommodation; the latter scenario, can generate frustrations amongst the larger minority that they are treated as equals to the smaller minorities. These differences are likewise glossed over in territories where there is no recognition. We cannot infer whether it is because the minority is simply too small or because they just barely missed the threshold. In these scenarios, how recognition (or its absence) affects speakers of the minority language will depend on their size.

\section{The moderating effects of linguistic diversity}

It is important that we consider the linguistic diversity of a community. We know from the political economy literature that linguistic diversity - often measured at the national level - negatively affects public goods provision (Miguel and Gugerty, 2005). The rationale is that there are certain attributes of multilingual societies that cause the under-provision. As a result, societies that are unwilling or unable to provide these necessary public goods - e.g., paved roads to facilitate movement of goods and people - end up with stunted growth (see Alesina, Baqir, and Easterly, 1999).

There are three groupings of mechanisms linking diversity with low economic growth (Habyarimana et al., 2009): incongruent preferences, challenges of collec- 
tive action, and differential behavior concerning the ingroup. First, preferences may vary between groups concerning the types of public goods and the intended beneficiaries. Since people in the same group are more likely to value processes and outcomes similarly, they are also more inclined to work together. As a result, consensus-building within groups leads to increased income levels. However, when people from different groups work together, the incongruence in preferences (e.g., location) means we are less likely to see public goods provision.

The next grouping of mechanisms captures the challenges of collective action within groups. Groups can leverage shared cultural values to acquire public goods. Additionally, shared language among group members strengthens communication. Misunderstandings about cultural references are also less likely to occur because of mutual understandings (Liu et al., 2015). These findings suggest that homogeneous communities are more conducive to efficient bargaining and decision making than diverse communities. The literature also notes that findability (i.e., the ability to find one another) makes social sanctioning easier within the ingroup (Miguel and Gugerty, 2005). Findability limits group members' capacity to evade responsibility. Both the ability to punish and the associated increases in trust promote public goods provision.

The final grouping of mechanisms focuses on cooperation between members of the ingroup and those in the outgroup. Homogeneous communities may develop norms and cooperative behaviors that apply exclusively to ingroup members. These mechanisms concern what group members will do rather than what they can do. Ingroup cooperation is more likely when everyone can sanction shirking - but only members of the ingroup do so. As a result, this behavior encourages cooperation exclusively among the ingroup. When the transaction costs of economic cooperation are lower in the ingroup (because of higher trust), the overall costs are also lower - thereby increasing income. Note, however, that the flip side of this ingroup sanctioning is limited cooperation with those in the outgroup.

Minority language recognition - in particular, at the subnational unit - can alter these incentives for intergroup cooperation by attenuating differences in preferences, minimizing barriers to collaboration, and making it easier to sanction. When governments accommodate minority languages in the provision of public services (i.e., public administration), there are several notable benefits. The first is that recognition acknowledges diversity. This recognition builds institutional trust among those in the minority who feel valued (Huebert and Liu, 2017; Liu and Baird, 2012). This matters for economic development. Second, when governments send such messages, people may be encouraged to learn the minority language - whether it is because they want to or need to (Liu and Pizzi, 2018). As more people know more languages, these interactions allow for the development, 
understanding, and communication of similar preferences. Moreover, switching between languages to communicate - regardless of fluency in the learned language - can facilitate efficiency. People understand the implied unit of transaction; people are comfortable correcting misunderstandings; and people trust that they can interact with each other in the future. Efficient and effective communication is important for economic exchanges.

There is, however, a limit to how much recognition can encourage intergroup engagement. When the minority constitute the overwhelming majority in an area, it is both logistically practical and normatively right to allow for their language to be used. Yet this comes with an economic risk. In these areas, the minority has no incentive to not use their own native language in all public matters. The preference for using the minority language hampers proficiency in the national language - thereby making the area functionally a linguistic enclave. The dominance of the minority language can have implications for how the rest of the country engages with the area. For example, there may be fewer resources for infrastructure development. The national government may be less inclined - whether consciously or subconsciously - to allocate funds for building a highway. Private investors - both from the rest of the country and abroad - are more likely to perceive this linguistic barrier as a cost and are thus discouraged from investing (Kim et al., 2015). Altogether, in areas where the minority are numerically dominant, we see suppressed economic development. Given this discussion, we hypothesize the following effect:

Hypothesis: Minority language recognition has a positive effect on economic wellbeing in areas with diversity.

\section{Research design}

To test our argument, we focus on Transylvania, Romania (Transilvania in Romanian; Erdély in Hungarian, Siebenbürgen in German). Transylvania offers several empirical advantages. The first is the application of the territoriality principle. According to the 2001 Law on Local Administration, a minority language is considered a working language of the local administrative territory if the minority constitutes more than $20 \%$ of the population in that unit (Horváth I., 2009; Salat and Novák, 2015; Toró, 2020). Two comments merit discussion. First, relative to other countries with a territoriality principle, a $20 \%$ threshold is high. In Finland, for example, the threshold is $8 \%$. Likewise, in the United States, minorities have the legal right - under the 1965 Voting Rights Act - to have their language appear on ballots when they constitute $5 \%$ of the voting district population and when the group's (English) illiteracy rate is higher than the national rate. Second, and more 
importantly, the threshold is strictly about relative size. It does not consider the absolute numbers for the minority population in a unit (Csata and Marácz, 2016; Wickström, 2019). The prime example is Cluj, the second most populous city in Romania. According to the 2011 census, Cluj has a total population of 325,000 , of which 50,000 is Hungarian - making Cluj home to the second largest Hungarian population in Romania. Yet, because of the $20 \%$ threshold, Hungarian is not a recognized administrative language (see Liu et al., 2018). In our sample, more than $28 \%$ of the territorial-administrative units recognize a minority language.

The second empirical advantage for focusing on Transylvania is its linguistic diversity: $74.3 \%$ speak Romanian; 19.5\%, Hungarian; $1.6 \%$, Romani; and $0.5 \%$, German. The territoriality principle applies to any minority language. Transylvania is home to a large Hungarian minority population - one of the largest minority populations in all of Europe. There is also a German minority population, although use of the German language is less pronounced. It is also interesting to note that the current Romanian president, Klaus Iohannis, is an ethnic German from Transylvania (Sibiu) who speaks German as his native language. Finally, there is a sizable Romani population. But because of the inherent diversity of the Romani vernaculars - i.e., there is no standardized, accepted written language and because of systemic discrimination (Csata, Hlatky, and Liu, 2020), Romani is not recognized as an administrative language in any public setting.

Our unit of analysis is the municipality, specifically the communes ${ }^{2}$ $(N=1043)$, the equivalent of the Local Administrative Unit (LAU) 2 in the European Union's (EU) Nomenclature of Territorial Units for Statistics (NUTS). Note that focusing on the municipality offers us two advantages. First, from a legal standpoint, the $20 \%$ threshold is determined at this level. Second, from an empirical standpoint, focusing on such a small administrative unit gives us the necessary leverage to identify the effects of minority language recognition on economic well-being (see Kiss, 2018).

\section{Dependent variable: Four measures of economic well-being}

The most common measures for economic development include GDP per capita (Arcand and Grin, 2013), economic growth (Liu, 2015), or public goods provision (Alesina, Baqir, and Easterly, 1999). Unfortunately, we cannot use these measures since the data is - if available at all - not comprehensive at the municipal level. As an alternative, we employ four different measures that we believe holistically capture economic well-being.

2. Communes are rural municipalities. In contrast, urban municipalities are classified as towns. We only look at communes because of the inherent differences in development between urban and rural areas (Ionescu-Heroiu et al., 2013). 
The first is municipal revenues per capita (currency: Romanian Lei). Municipal revenue is made up of individual income tax revenues and revenues from local taxes (e.g., real estate tax and car tax) - as reported by the Ministry of Regional Development and Public Administration. ${ }^{3}$ We focus on municipal income for two reasons. First, our unit of analysis is not the individual but the administrative territory. Second, revenues of the municipal government matter for the provision of public services and investments - arguably even more so than a high average income due to a few very wealthy individuals in the village skewing the mean upwards.

In Romania, municipalities have a role in deciding what tax is levied. There is, however, a maximum threshold set by Bucharest for every type of tax. Moreover, the municipalities have limited authority to assess the tax base or enforce the tax collections. This usually falls under the purview of the national government. Note that while the taxes of non-resident owners can be theoretically included in the revenues, the contrary is certainly not the case - i.e., our measure does not include non-residential revenues from the outside. Finally, commercial vehicles are included.

We have data for three consecutive years (not months). We calculate the average over the entire period (2016-2018) and standardize it given the population of the municipality. Average municipal revenue per capita ranges from a minimum of 160.44 to a maximum of 5855.22 , with a mean of 564.11 .

The second measure is an index of human development also at the municipal level (LHDI; Ionescu-Heroiu, Burduja, and Sandu, 2013, p.238). The index is based on the factor scores from a principal component analysis comprised of six constituent elements from four dimensions: human capital (the average education level for the commune); health capital (life expectancy at birth for the commune); vital capital (the average adult population age for the commune); and material capital (average living space per dwelling, gas consumption per capita, and number of cars per 1,00o inhabitants in the commune). The index ranges from 29 (Măgherani in Mureș County) to 140 (Dumbrăvița in Timis County) where higher values suggest more development. Data are from 2011.

The third indicator looks at business activities. The intuition is that as the economy grows, the number of enterprises will increase. Here, we extract from a balance sheet of firms and cooperative associations for the accounting year 2018, which was published by the Ministry of Finance. ${ }^{4}$ We focus exclusively on com-

3. 'Statements on the Revenues and Expenditures of the Administrative-Territorial Units of the Ministry of Regional Development and Public Administration.' http://www.dpfbl.mdrap.ro/sit _ven_si_chelt_uat.html (Accessed 13 June 2021).

4. https://data.gov.ro/dataset/situatii_financiare_2018 (Accessed 13 June 2021). 
panies based in Romania with a positive turnover in 2018. We do not include firms engaged in financial activities in the analysis. Moreover, we do not consider sole proprietorships and family businesses since they are not reported in the database. We standardize the number of active businesses per 1,000 inhabitants. The average business density for our sample is 14.1. The range is quite large. At one end there are the likes of Batrâna (Hunedoara County), Crăiești (Mureș County), and Vețca (Mureș County) with a density of o. At the other end are Sâniob (Bihor County), Coronini (Caraș-Severin County), and Dumbrăvița (Timiș County) with densities greater than 154.

Finally, we focus on the change in housing stock. As the economy grows, people will have more resources to buy or build houses. Here, we measure for stock specifically, the change in stock - by taking the difference between 2011 and 2017. We standardize it by the 2011 numbers. All figures are from the National Institute of Statistics. ${ }^{5}$ For all of Transylvania, the number of houses built increased by $2.16 \%$ - with 29 municipalities seeing shrinkage. Table 1 summarizes each data used.

Table 1. Different measure of economic well-being

\begin{tabular}{|c|c|c|c|c|}
\hline What & When & Operationalized & Data source & Descriptives \\
\hline $\begin{array}{l}\text { Municipal } \\
\text { Revenues } \\
\text { Individual } \\
\text { income tax } \\
\text { revenues and } \\
\text { revenues from } \\
\text { local taxes (e.g., } \\
\text { real estate and } \\
\text { car). }\end{array}$ & $2016-2018$ & $\begin{array}{l}\text { Average over three-year } \\
\text { period - per municipality } \\
\text { population. }\end{array}$ & $\begin{array}{l}\text { Ministry of } \\
\text { Regional } \\
\text { Development } \\
\text { and Public } \\
\text { Administration }\end{array}$ & $\begin{array}{l}\text { Min: } 160.4 \\
\text { Mean: } 564.1 \\
\text { Max: } 5855.2\end{array}$ \\
\hline $\begin{array}{l}\text { Local HDI } \\
\text { Index of (1) } \\
\text { human capital; } \\
\text { (2) health } \\
\text { capital; (3) vital } \\
\text { capital; and (4) } \\
\text { material capital. }\end{array}$ & 2011 & $\begin{array}{l}\text { Factor scores of (1) average } \\
\text { education level; (2) life } \\
\text { expectancy at birth; (3) average } \\
\text { age of adult population; (4) } \\
\text { average living space per } \\
\text { dwelling; (5) gas consumption } \\
\text { per capita, and (6) number of } \\
\text { cars per } 1000 \text { inhabitants - per } \\
\text { commune. }\end{array}$ & $\begin{array}{l}\text { Ministry of } \\
\text { Finance }\end{array}$ & $\begin{array}{l}\text { Min: } 29 \\
\text { Mean: } 57.8 \\
\text { Max: } 140\end{array}$ \\
\hline
\end{tabular}

5. Statistical research on housing fund changes. National Institute of Statistics, Romania. Table no. LOC101B http://statistici.insse.ro:8077/tempo-online/\#/pages/tables/insse-table (Accessed 13 June 2021). 
Table 1. (continued)

\begin{tabular}{|c|c|c|c|c|}
\hline What & When & Operationalized & Data source & Descriptives \\
\hline $\begin{array}{l}\text { Business } \\
\text { Activities } \\
\text { Balance sheet } \\
\text { of firms and } \\
\text { cooperative } \\
\text { associations } \\
\text { (minus } \\
\text { financial firms, } \\
\text { sole } \\
\text { proprietorships, } \\
\text { and family } \\
\text { businesses). }\end{array}$ & 2018 & $\begin{array}{l}\text { All companies based in } \\
\text { Romania with a positive } \\
\text { turnover in } 2018 \text {-per } 1000 \\
\text { inhabitants. }\end{array}$ & $\begin{array}{l}\text { Ministry of } \\
\text { Finance }\end{array}$ & $\begin{array}{l}\text { Min: o } \\
\text { Mean: } 14.1 \\
\text { Max: } 154\end{array}$ \\
\hline $\begin{array}{l}\text { Housing Stock } \\
\text { Number of } \\
\text { houses built. }\end{array}$ & 2011,2017 & $\begin{array}{l}\text { Change in number of houses - } \\
\text { standardized - per number of } \\
\text { houses in } 2011 .\end{array}$ & $\begin{array}{l}\text { National } \\
\text { Institute of } \\
\text { Statistics }\end{array}$ & $\begin{array}{l}\text { Min: }-1.3 \% \\
\text { Mean: } 2.2 \% \\
\text { Max: } \\
126.9 \%\end{array}$ \\
\hline
\end{tabular}

Independent variable 1: Territoriality principle

Our key independent variable is the territoriality principle. Specifically, we are interested in whether a minority language is recognized for official use in public administration. We code Territoriality Principle as a ' 1 ' if either the Hungarian and/or other minority population constitutes at least $20 \%$ of the commune population. Data for this comes from the 2011 Census. Otherwise, the variable is assigned a value of ' 0 '. Almost $30 \%$ of the municipalities $(N=296)$ in Transylvania recognize a minority language.

Independent variable 2: Linguistic fractionalization

To test the conditional effects of diversity, we construct a linguistic fractionalization measure for each municipality. Specifically, we use the following Herfindahl Index:

$$
H=1-\sum_{i=1}^{n} s_{i}^{2}
$$

where $s_{i}$ is the proportion of each linguistic group $i(i=1, \ldots, n)$. This index measures the probability of randomly drawing two people who speak two different languages. A minimum value of o suggests every individual in that municipality speaks the same language. In contrast, a maximum value of 1 indicates that each 
person speaks a different language. As we see in Figure 1, linguistic fractionalization in Transylvania ranges widely from o (135 municipalities) to a maximum of 0.64 (Ormenis in Brasov County) - with a mean of 0.15 .

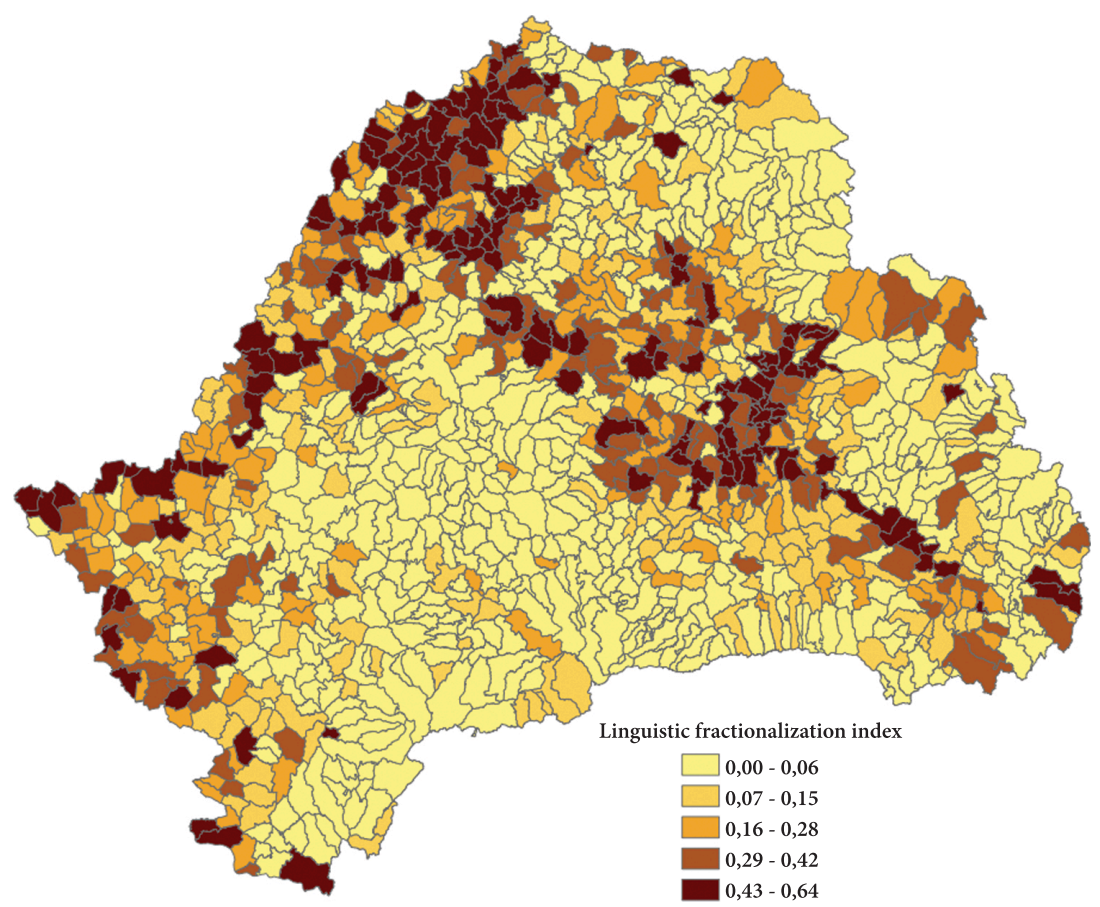

Figure 1. Linguistic fractionalization in Transylvania, Romania (Municipalities, 2011)

The correlation between linguistic fractionalization and whether there is minority language recognition is 0.55 . Here it is important to note that just because an area is linguistically homogeneous does not mean the homogeneity is in Romanian. In fact, if we look at the areas with linguistic fractionalization of less than $0.10,{ }^{6} 83$ of the municipalities (14.2\%) are Hungarian - yet both Romanian and Hungarian are languages of public administration. Table 2 shows the variation in linguistic fractionalization between areas that recognize minority languages and those that do not.

6. As examples globally, Saudi Arabia is a 0.094 and Denmark is a 0.105 . 
Table 2. Linguistic fractionalization across the territoriality principle

\begin{tabular}{lccccc}
\hline & N & Mean & SD & Min & Max \\
\hline No minority language recognition & 747 & 0.09 & 0.12 & 0.00 & 0.55 \\
Minority language recognized & 294 & 0.31 & 0.20 & 0.00 & 0.65 \\
\hline
\end{tabular}

\section{Control variables}

We consider other possible confounding factors for explaining income levels (Ionescu-Heroiu et al., 2013). We control for population numbers since size can affect the supply-and-demands of the market. Additionally, geography can matter. Consider how large distances and/or the absence of roads can hamper development. Given this discussion, we look at municipality size - i.e., population numbers according to the 2011 Census. We also control for how far the municipality center is from the nearest town or urban center (unit: kilometers), whether there is a European road crossing through the municipality, and the number of villages belonging to the municipality (data source: Sandu, 2011). There are also reasons to believe institutional quality can affect economic development (Bracic, 2020). When civic participation is widespread - i.e., there is a rich, democratic engagement - this can facilitate cultural understanding and interlingual communication. To measure public participation, we use two proxies: the number of non-government organizations per 1,000 inhabitants (from the Ministry of Justice, National Register of NGOs) ${ }^{7}$ and the participation rate in the 2016 local elections. ${ }^{8}$ See Table 3 for descriptive statistics.

\section{Empirical evidence}

We estimate our models using ordinary least squares with robust standard errors given the continuous nature of our dependent variables. To get the general intuition as to whether the effects of the territoriality principle are positive - subject to linguistic diversity - we first run a series of split sample baseline models with linguistic fractionalization bracketed into differing bands (see Table 4). We start with areas of substantial diversity - e.g., there are at least two groups of equal size. Model $1 a$ shows that when fractionalization is 0.50 or greater, minority language recognition has a positive, significant effect on municipal revenues $(\beta=158.28$; $S E=67.16)$. We lose the positive sign when fractionalization shifts to between

7. https://data.gov.ro/dataset/registrul-national-ong (Accessed 16 July 2020).

8. http://www.2016bec.ro/rezultate-finale-10-o6-2016/index.html (Accessed 16 July 2020). 
Table 3. Descriptive statistics of Transylvanian municipalities

\begin{tabular}{lrrrcr}
\hline & N & Mean & SD & Min & Max \\
\hline Municipal Revenues per Capita (2016-2018) & 1041 & 564.11 & 429.94 & 160.44 & 5855.22 \\
Local Human Development (2011) & 980 & 57.79 & 9.83 & 29 & 140 \\
Business Activities (2018) & 1041 & 14.11 & 12.27 & 0 & 154.75 \\
Housing Stock (Change 2011, 2017) & 1041 & 2.16 & 7.65 & -1.26 & 126.92 \\
Territoriality Principle & 1043 & 0.28 & 0.45 & 0 & 1 \\
Linguistic Fractionalization (2011) & 1041 & 0.15 & 0.18 & 0.00 & 0.64 \\
Population Size (2011) & 1041 & 2803 & 1669 & 119 & 22813 \\
Nearest Town (kilometers) & 982 & 18.79 & 9.95 & 2 & 71 \\
Nearest City (kilometers) & 982 & 36.17 & 23.03 & 3 & 140 \\
European Road (1=Yes) & 982 & 0.22 & 0.41 & 0 & 1 \\
Number of Villages & 982 & 4.53 & 2.62 & 1 & 15 \\
\# NGOs (per 10oo people, logged) & 1041 & 3.88 & 2.61 & 0 & 25.21 \\
Election Turnout (\% 2016) & 1043 & 61.4 & 11.42 & 0 & 100 \\
\hline
\end{tabular}

0.40 and 0.50 (Model 16$)$; however, the coefficient is non-significant $(\beta=-64.93$; $S E=69.74)$. The non-significance is robust across each subsequent decile until we get to fractionalization at 0.10 or lower (Model $1 f$ ). Here, we see the coefficient is both negative and significant $(\beta=-257.15 ; S E=59.52)$. This suggests that in homogeneous areas - i.e., where the likelihood of finding two different languages is less than $10 \%$ - minority language recognition has a negative effect on municipal revenues. This general pattern is consistent with our argument that the benefits of minority language recognition manifest themselves primarily in diverse areas. While the precise tipping point for where the effects flip varies for each measure of economic well-being (more below), the general pattern holds whether we are looking at human development, business density, or housing stock.

Next, we run the regression model on the full sample where we include an interaction term of territoriality principle and linguistic fractionalization. Moreover, we model for county fixed effects. This allows us to control for possible latent unobserved effects - e.g., the effects of voting for the Hungarian ethnic party. ${ }^{9}$ The results in Model 2 show that while the direction of the two constituent terms is negative, their conditional effect is positive and significant $(\beta=378.82$; $S E=149.19)$. To ease interpretation, we plot the predicted values of municipal rev-

9. We also run the models with region fixed effects (namely, north-west, west, and center). The results remain robust across different model specific specifications. 


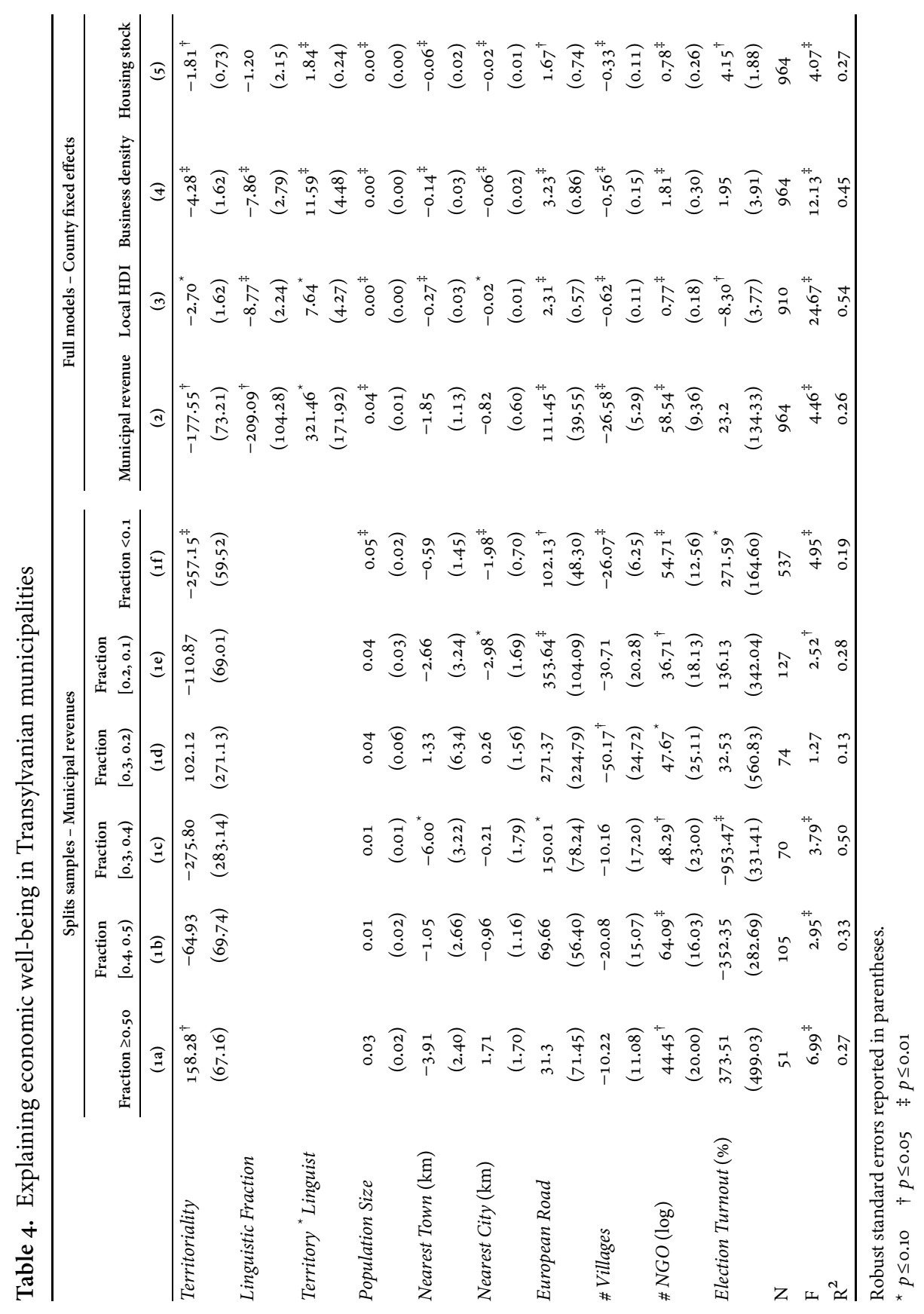


enues for the territoriality principle given the full range of linguistic fractionalization (see Figure 2a). The results mirror those we saw in the split sample: the territoriality principle matters for municipal revenues - but how it matters is subject to linguistic diversity. When the Romanians and Hungarians are roughly of equal size, minority recognition has a positive, significant effect. Moreover, the positive effects of recognition manifest themselves generally even when one group is somewhat larger than the other. However, in areas where Hungarians are the overwhelming majority, recognition has a significant, negative effect.

We observe this general pattern when we look at the other measures of economic well-being. Linguistic recognition increases economic well-being whether it is human development ( Model $_{3}: \beta=7.64 ; S E=4.27$ ), business activities (Model 4: $\beta=11.59 ; S E=4.48$ ), or housing stock (Model $5: \beta=1.84 ; S E=0.24)$ - as diversity increases. However, the caveat we discussed previously still manifests itself: in the more homogeneous municipalities, the recognition of the minority language can stunt economic development. In each case, the difference between not recognizing and recognizing a minority language is substantial. The human development index drops from 58.72 (CI: $58.08,29.36$ ) to 54.75 (CI: $53.17,56.32$ ) see Figure $2 \mathrm{~b}$. Likewise, density of business enterprises contracts from 15.06 (CI: $14.14,15.99$ ) down to 10.13 (CI: 8.04, 12.22) - see Figure 2c. Finally, housing stock shrinks from 2.77 (CI: 1.99, 3.54) to -0.24 (CI: -1.34, 0.87 ) - see Figure $2 \mathrm{~d}$.

Demography and geography both matter for economic well-being. Municipalities with large populations are more likely to have higher municipal revenues, human development, business density, and expansion in housing stock. In fact, population size exerts the strongest substantive effect of all the factors that we consider (twice the size of both language recognition and linguistic fractionalization). In terms of geography, the presence of a European road bolsters economic outcomes (138.12). As expected, proximity to towns or urban centers (greater than 30,000 population) has a positive effect. Finally, if a municipality is composed of multiple villages, economic well-being is likely to be stunted. The results also suggest that civic engagement matters for economic well-being. The number of NGOs in a municipality is positively associated with income levels (56.73) which admittedly could be the function of reverse causality, i.e., wealthier areas are able to support more NGOs.

\section{The Roma effect}

It is hard to talk about economic development in Romania without acknowledging the challenge surrounding the Roma. First, since the linguistic fractionalization numbers include the Roma population, it is important to recognize that in areas where there is no minority language recognition, the proportion of Romani 


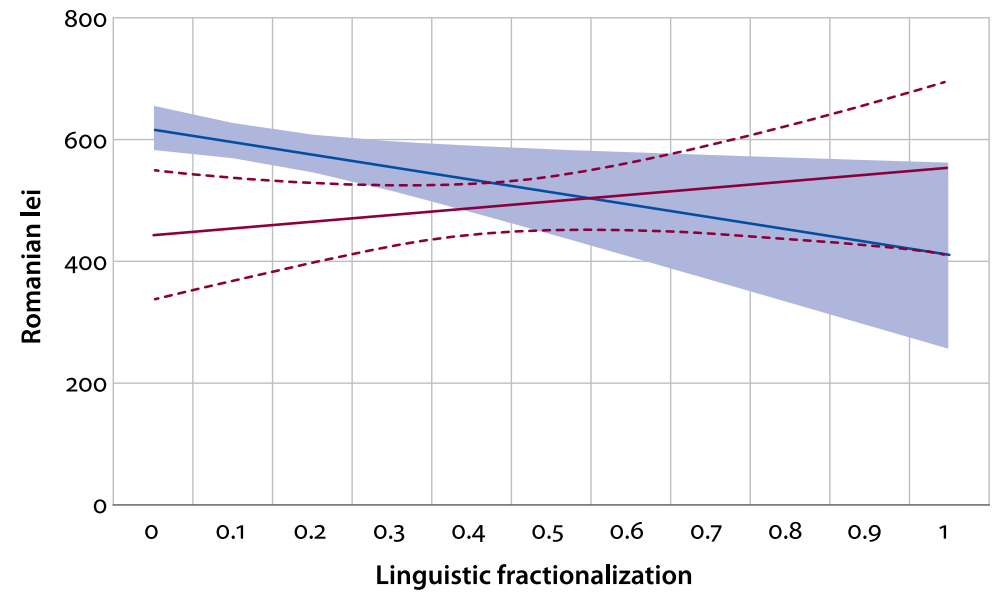

Min_L $\longrightarrow 20 \%$ (Recognition)

a. Municipal revenue per capita (2016-2018)

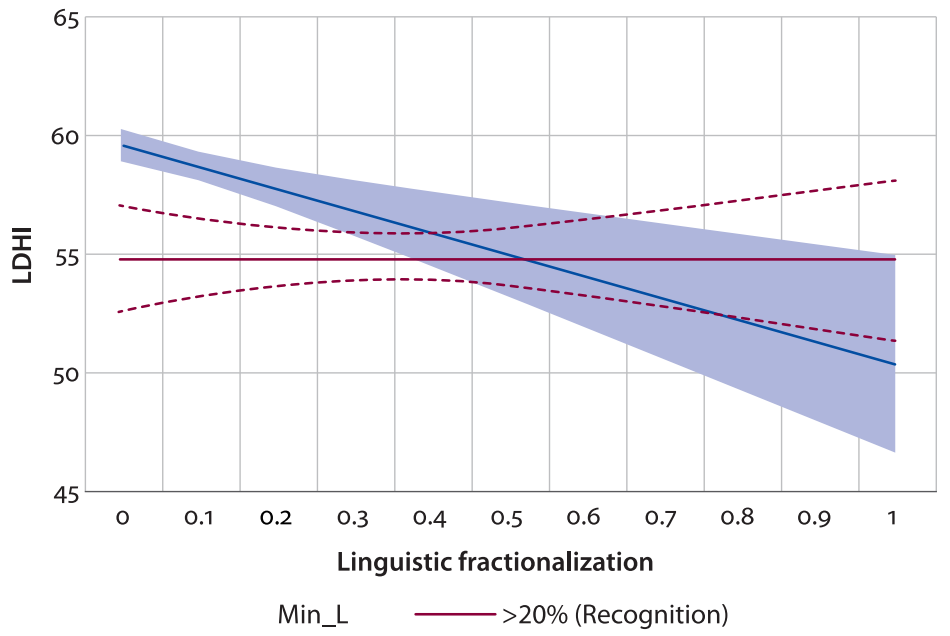

b. Local human development index (2011) 


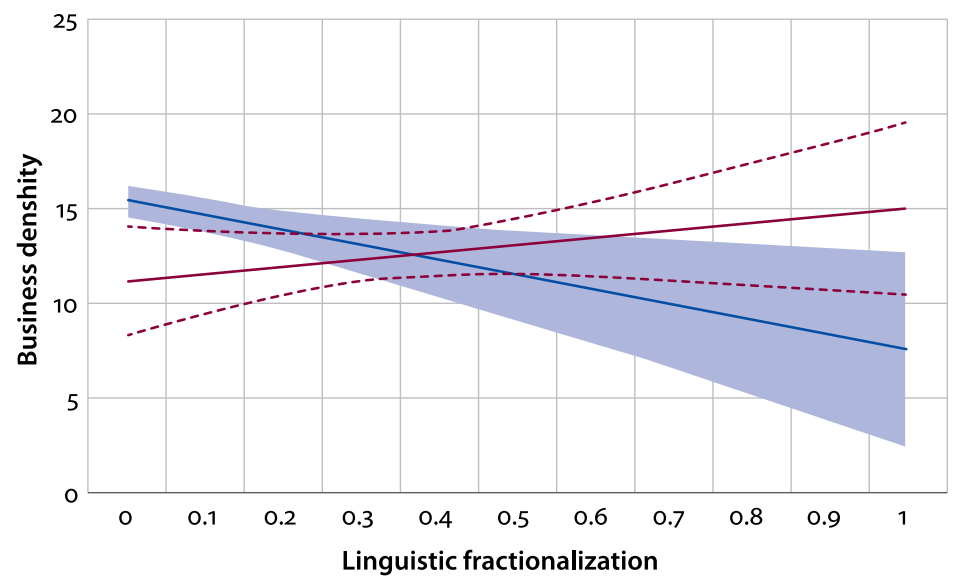

Min_L $\longrightarrow 20 \%$ (Recognition)

c. Business density (2018)

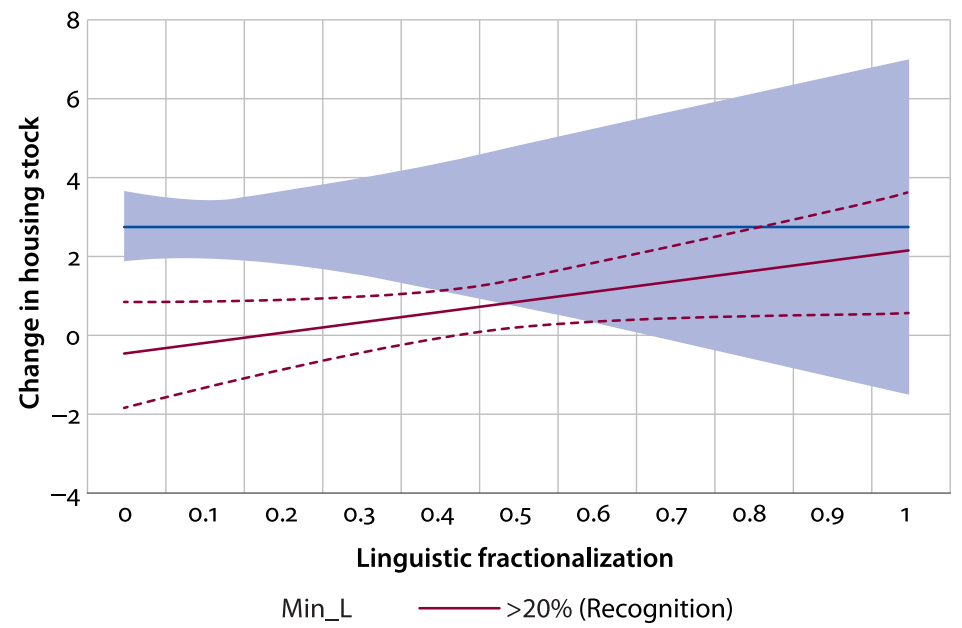

d. Change in housing stock (2011-2017)

Figure 2. Conditional effects of linguistic fractionalization on economic well-being

speakers explains $31 \%$ of the linguistic fractionalization variance; but in areas where a minority language is used in public administration, the Romani-speaking population constitute only $8 \%$ of the variance. Second, Roma face extreme poverty and discrimination - unlike any other linguistic minority group (Bracic, 2020; Csata, 2017; Fosztó, 2009). Indeed, in areas where the Roma constitute more than $20 \%$ of the population, Romani is not considered a working language. This 
discussion is important here since the effects that we find are possibly driven by the Roma population and not the territoriality principle.

To address this, we rerun the interactive model with a control for the number of Romani speakers in each municipality. The number of Romani speakers ranges from o (in 445 municipalities) to 1335 (Petelea in Mureș County). Note that this number is substantially smaller than the number of people identifying as Roma (about a one-third differential). We expect the effect of the number of Romani speakers to be significant and negative. We also expect our interaction term's coefficient to be attenuated somewhat - but it should still be significant. The results confirm this: The coefficient for the Romani-speaking population is negative and significant at the $p<0.05$ level $(\beta=-0.25 ; S E=0.06)$. Additionally, the coefficient for the interaction term is still positive and significant. The magnitude, however, is only $84 \%$ of what it was in our original model $(\beta=310.22$ versus $\beta=378.82)$ although the difference between the two coefficients is also not statistically significant. What this suggests is that while the Roma population does affect income levels, it is far from the only factor driving wealth accumulation.

\section{Conclusion}

In this paper we examined the effects of the territoriality principle in Transylvania. Specifically, we examined whether recognizing a minority language as a working language in an administrative unit can spur economic well-being. We find that recognition has a positive effect. Accommodation can facilitate intergroup trust, political confidence, and group worth - thereby parlaying into wealth accumulation. There is, however, a caveat. In areas with more homogeneity - specifically in areas where the minority are the numerical majority - recognition can further render the area a linguistic enclave. This can dissuade infrastructure development and investment interests.

This paper speaks to the extant scholarship on minority politics in Transylvania. Most of the attention has been on ethnic hierarchies from a socioeconomic perspective - namely, the status of the Hungarians relative to Romanians (Csata, 2017; Kiss, 2010, 2018). Absent is the explicit focus on the socioeconomic effects of the territoriality principle. This paper fills this critical gap.

These results suggest that while linguistic minorities may value being able to use their language in public administrative matters, there is a warning. The effects of accommodation are contingent on linguistic diversity. When municipalities are diverse, recognition of a second language facilitates interaction, communication, and understanding. In these cases, the distribution of diversity necessitates that individuals from different groups interact with one another. Not only does the ter- 
ritoriality principle foster these interactions, but it also facilitates communication between the minority group and the state. Moreover, it connotes a symbolic value and worth on the minority group. For these reasons, minority language recognition can bolster economic development.

Thus, for policymakers, we suggest a caution. Recognition needs to be more than just the law. Even in diverse areas, it cannot be mere window-dressing; it needs to be implemented appropriately. There is always a risk that in areas where the Hungarians are sizable but not a majority - e.g., between 20 and 50\% - Hungarian is not used adequately (Horváth, 2009; Horváth, Csata, and Székely, 2021; Toró, 2020). When this happens, there is a risk of escalating tensions and growing distrust - thereby undermining the very benefits of the territoriality principle.

If the territoriality principle is taken seriously, in places where the Hungarians and Romanians are 50-50, this could prove both empowering for the Hungarians without being detrimental for Romanians. This is more than symbolic. It is also important to remember that in most of the 2oth century, the Hungarian language had no official status. Yet, there was still de facto bilingualism - as evident in the collective memory among the elderly. Thus, linguistic ideologies among everyday Romanian people in regions with bilingual heritage might be more permissive towards bilingualism than what the nationalistic political discourses might suggest.

\section{Funding}

This research received funding from the National Research, Development and Innovation Office of Hungary (grant agreement no. FK 125276).

\section{References}

Alesina, A., Baqir, R., \& Easterly, W. (1999). Public goods and ethnic divisions. The Quarterly Journal of Economics, 114(4), 1243-1284. https://doi.org/10.1162/003355399556269

Arcand, J.L., \& Grin, F. (2013). Language in economic development: Is English special and is linguistic fragmentation Bad? In E. Erling \& P. Seargeant (Eds.), English and development: Policy, pedagogy and globalization 17 (pp. 243-261). Bristol, Blue Ridge Summit: Multilingual Matters. https://doi.org/10.21832/9781847699473-015

Boia, L. (2015). Cum s-a românizat România. București: Humanitas.

Bracic, A. (2020). Breaking the exclusion cycle: How to promote cooperation between majority and minority ethnic groups. Oxford: Oxford University Press. https://doi.org/10.1093/oso/9780190050672.001.0001

Csata, Z. (2017). Munkaerőpiaci egyenlőtlenségek Romániában, etnikai metszetben. Erdélyi Társadalom, 15(1), 81-103. 
Csata, Z. (2018). Economy and Ethnicity in Transylvania. In T. Kiss, I. Székely, T. Toró, N. Bárdi \& I. Horváth (Eds.), Unequal accommodation of minority rights (pp. 345-379). Cham: Palgrave Macmillan. https://doi.org/10.1007/978-3-319-78893-7_9

Csata, Z., Hlatky, R., \& Liu, A.H. (2020). How to head count ethnic minorities: Validity of census surveys versus other identification strategies. East European Politics. https://doi.org/10.1080/21599165.2020.1843439

Csata, Z., \& Marácz, L.K. (2016). Prospects on Hungarian as a regional official language and Szeklerland's territorial autonomy in Romania. International Journal of Minority and Group Rights, 24(1), 1-30. https://doi.org/10.1163/15718115-02304005

De Schutter, H. (2008). The linguistic territoriality principle: A critique. Journal of Applied Philosophy, 25(2), 105-120. https://doi.org/10.1111/j.1468-5930.2008.00397.x

den Butter, F.A., \& Mosch, R.H. (2003). Trade, trust and transaction cost. Amsterdam and Rotterdam: Tinbergen Institute Discussion Paper, 03-082/3. https://doi.org/10.2139/ssrn.459501

Fosztó, L. (2009). Colecţie de studii despre romii din România. Cluj Napoca: Editura ISPMN.

Ginsburgh, V., \& Weber, S. (2011). How many languages do we need?: The economics of linguistic diversity. Princeton: Princeton University Press.

Habyarimana, J., Humphreys, M., Posner, D. N., \& Weinstein, J. (2009). Coethnicity: Diversity and the dilemmas of collective action. New York: Russell Sage.

Horváth, I. (2009). A romániai nyelvpolitikák értékelése. Regio, 2o(1), 3-16.

Horváth, I., Csata, Z., \& Székely, I. G. (2021). Utilizarea limbii materne la nivelul unităților administrative locale: Estimare costuri. Cluj Napoca: Institutul Pentru Studierea Problemelor Minorităţilor Naţionale.

Huebert, E. T. \& Liu, A.H. (2017). Ethnic identity and attitudes toward state institutions: Evidence of judicial legitimacy among the indigenous in Latin America. Politics, Groups, and Identities, 5(4): 561-579. https://doi.org/10.1080/21565503.2015.1136223

Ionescu-Heroiu, M., Burduja, S., \& Sandu, D. (2013). Competitive cities: Reshaping the economic geography of Romania: Report. Washington, D.C.: World Bank.

Kim, M., Liu, A.H., Tuxhorn, K.-L., Brown, D.S., \& Leblang, D. (2015). Lingua mercatoria: Language and foreign direct investment. International Studies Quarterly, 59(2): 330-343. https://doi.org/10.1111/isqu.12158

Kiss, T. (2010). Támpontok az erdélyi etnikai rétegződési rendszer vizsgálatához II. Pro Minoritate, 2, 3-42.

Kiss, T. (2018). A changing system of ethnic stratification: The social positions of Transylvanian Hungarians. In T. Kiss, I. Székely, T. Toró, N. Bárdi \& I. Horváth (Eds.), Unequal accommodation of minority rights (pp. 419-458). Cham: Palgrave Macmillan. https://doi.org/10.1007/978-3-319-78893-7_11

Knack, S., \& Keefer, P. (1997). Does social capital have an economic payoff? A cross-country investigation. Quarterly Journal of Economics, 112(4), 1251-1288. https://doi.org/10.1162/003355300555475

Liu, A.H. (2015). Standardizing diversity: The political economy of language regimes. Philadelphia: University of Pennsylvania Press. https://doi.org/10.9783/9780812292107

Liu, A.H., \& Baird, V. (2012). Linguistic recognition as a source of confidence in the justice system. Comparative Political Studies, 45(10), 1203-1229. https://doi.org/10.1177/0010414011434294

Liu, A.H., Brown, D.S., \& Dunn, M.H. (2015). Minority language recognition and trust: Evidence from twenty-five democracies. Taiwan Journal of Democracy, 11(2), 113-138. 
Liu, A.H., \& Pizzi, E. (2018). Language of economic growth: A new measure of linguistic heterogeneity. British Journal of Political Science, 48(4), 953-980. https://doi.org/10.1017/Sooo7123416000260

Liu, A.H., Shair-Rosenfield, S., Vance, L. R., \& Csata, Z. (2018). Linguistic origins of gender equality and women's rights. Gender and Society, 32(1), 82-108. https://doi.org/10.1177/0891243217741428

Marquardt, K.L. (2018). Identity, social mobility, and ethnic mobilization: Language and the disintegration of the Soviet Union. Comparative Political Studies, 51(7), 831-867. https://doi.org/10.1177/0010414017720701

Miguel, E., \& Gugerty, M.K. (2005). Ethnic diversity, social sanctions, and public goods in Kenya. Journal of Public Economics, 89(11-12), 2325-2368. https://doi.org/10.1016/j.jpubeco.2004.09.004

Putnam, R.D. (2007). E pluribus unum: Diversity and community in the twenty-first century. Scandinavian Political Studies, 30(2), 137-174. https://doi.org/10.1111/j.1467-9477.2007.00176.x

Ricks, J. I. (2020). The effect of language on political appeal: Results from a survey experiment in Thailand. Political Behavior, 42(1), 83-104. https://doi.org/10.1007/s11109-018-9487-z

Salat, L., \& Novák, C.Z. (2015). Ethnicity, nationalism, and the minority regime. In L. Stan \& D. Vancea (Eds.), Post-communist Romania at twenty-five: Linking past, present, and future (pp. 63-86). Lanham: Lexington Books.

Sandu, D. (2011). Social disparities in the regional development and policies of Romania. International Review of Social Research, 1(1), 1-30. https://doi.org/10.1515/irsr-2011-0001

Toró, T. (2020). Detached implementation: Discourse and practice in minority language use in Romania. Language Policy, 19(1), 5-29. https://doi.org/10.1007/s10993-018-9494-2

Van Parijs, P. (2011). Linguistic justice for Europe and for the world. Oxford: Oxford University Press. https://doi.org/10.1093/acprof:osobl/9780199208876.001.0001

Wickström, B.A. (2019). The percentage rule for minority language rights: Inadequate or discriminatory. Język. Komunikacja. Informacja, 14: 72-84.

Wolff, S. (2009). Ethnic minorities in Europe: The basic facts. Nottingham: Centre for International Crisis Management and Conflict Resolution.

\section{Resumo}

La teritoria principo stipulas, ke minoritataj komunumoj en difinita teritorio estu lingve akomodataj. Kiajn ekonomiajn efikojn havas tiu principo? En la nuna studo, ni argumentas, ke la rekono de pluraj lingvoj donas respekton al la minoritata grupo: ĝi permesas, ke homoj engaĝiĝu kaj signife partoprenu en la socio - tiel faciligante ekonomian bonfarton. Tamen, necesas averto: Kiam la rekono okazas en regionoj kie la minoritato konsistigas vaste superan plimulton, oni riskas, ke la minoritata lingvo fortranĉu la komunumon disde la pli granda nacia stato, kio siavice stumpigas la disvolviĝon. Por elprovi tion, ni jetas nian rigardon al Transilvanio, Rumanio. Ni apogas nin je jura stipulo kiu rekonas minoritatajn lingvojn en regionoj kie la minoritato konsistigas pli ol $20 \%$ de la enloĝantaro. Utiligante informojn el la municipa nivelo, ni trovas, ke rekono generale plifortigas ekonomian bonfarton - sed ne en regionoj kie la minoritato laŭnombre dominas. Niaj rezultoj estas norme bonvenaj, sed ili ankaŭ atentigas registarojn, ke ili ne simple rekonu minoritatajn lingvojn, sed ankaŭ protektu ilin adekvate. 


\section{Összefoglaló}

A területiségi elve szerint a kisebbségi közösségek számára biztosítani kell a saját nyelvhasználat lehetőségét azokban a régiókban, ahol a nyelvközösség mérete és népességbeli aránya meghalad egy bizonyos küszöböt. Ebben a tanulmányban amellett érvelünk, hogy több nyelv elismerése gazdasági előnyökkel jár, mert megbecsülést ad a kisebbségi csoportoknak, ösztönzi a társadalomban való aktív és jelentőségteljes részvételüket. Ugyanakkor fennáll a veszélye annak, hogy azokban a régiókban, ahol a nyelvi kisebbség jelentős számbeli többségben van, a kisebbségi nyelv szinte kizárólagos használata oly mértékben csökkenti a többségi nyelvvel szembeni kitettséget, hogy beszükülnek a többségiekkel fenntartott intézményes kapcsolatok, ez pedig a gazdasági fejlődés akadályává válhat. A tanulmányban azt vizsgáljuk, hogy ez a jelenség mennyire jellemző Erdélyben, ahol a törvény a kisebbségi nyelv hivatalos használatát a nyelvközösség 20\%-os aránya fölött írja elő. A községszintü adatokon végzett elemzés azt mutatja, hogy csak ott van pozitív összefüggés a kisebbségi nyelvhasználat elismerése és az önkormányzatok bevételei között, ahol az egyik nyelvi csoport sincs domináns többségben. Eredményeink ugyan normatív szempontból üdvözlendőek, ugyanakkor felhívják a figyelmet arra, hogy nem elég a kisebbségi nyelvek jogi elismerése, annak megfelelő végrehajtatását is biztosítani kell.

\section{Address for correspondence}

\section{Zsombor Csata}

Centre for Social Sciences

Institute for Minority Studies

Tóth Kálmán u. 6

Budapest 1097

Hungary

csata.zsombor@tk.hu

https://orcid.org/oooo-ooo1-9167-8260

\section{Co-author information}

\section{Roman Hlatky}

Department of Government

University of Texas at Austin

rohlatky@utexas.edu

(iD https://orcid.org/oooo-ooo1-8378-2877
Amy H. Liu

Department of Government

University of Texas at Austin

amy.liu@austin.utexas.edu

(iD) https://orcid.org/oooo-ooo1-5380-2849

Ariel Pitre Young

Department of Government

University of Texas at Austin

arielyoung@utexas.edu 


\section{Publication history}

Date received: 1 May 2021

Date accepted: 31 July 2021

Published online: 24 November 2021 